\title{
4. 結言
}

大地電位が変動する場合自然電位分と変動電位分を分 離して自然電位分を求めるため，ブラウン管を使用した 大地電位差直視装置を試作した。日立鉣山の既知鉣床附 近の約 $200 \mathrm{mV}$ の負中心に対して実験を行つた結果変動

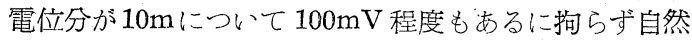
電位分布は夜間測定の結果ともよく一致し，明暸に負中

1951年 2 月19-22日の 4 日間に二亘つてミゾリー州の St. Louis で開かれたアメリカ鉱山冶金学会の年会に 於てィリノィ大学の地質学教授 R.E. Grim 博士の司 会の下で行われた粘土及びラテラィト鉱床の生成!関 す方諸問題の討論会の結果を䌆めたものである。

参加した人々はR. Roy, E.F. Osborn, T.F. Bates, R.E. Grim, T.S. Lovering など粘土鉣物の権威, 母岩の変質の研究者などであつて，この種鉣床の座状 に関するもの 8 編, 粘土鉱物!関寸るもの, 成因に関 するもの併せて 11 編, 高温高圧下の $\mathrm{Al}_{2} \mathrm{O}_{3}-\mathrm{SiO}_{2}-\mathrm{H}_{2} \mathrm{O}$ 系の実験に関するもの 1 編，粘土鉣物の利用に関する もの 1 編, 討論の項 1 編からなつている。

最も時代の若い鉱床としてはハワィのラテラィト 鉣床学挙げることができ る。ここでは 1 年間!こ降雨 量10’に满たず 熱帯的気温 にさらされている部分と， 年 600 の降雨量で温暖な地 域とがあって，立武岩を母

\section{粘土及びラテライトの成因に関する} 諸問題の討論会

Problems of Clay and Laterite Genesis, Symposium, AIME, 1952

心を確めることが出来た。なお変動電位の大きさ及び方 向を測定することが出来るので，これを探鉱上に利用す ることも考えられるが，その方法については更に研究を 要する点が多い。

終りに現場実験に際して御協力下さつた日本鉱業本社 本多共之氏，百瀬寛人氏，日立鉱山島田衛氏，島田敏郎. 氏外各位に感謝の意を表する次第である。

ギプス石などが特徵的である。又，風化の程度の弱い 部分ではカオリンが，風化の程度の甚しいところでは ボーキサイトを生ずる。文，粒度の粗い部分と細加、 部分とではかなり組成鉱物を異にする事がある。

鈗物が風化によつて変化する順序は大体モンモり口 ン石, カオリン, 水酸化鉄, 鉄-Ti-酸化物の順位である。 従つて鈗物としては，モンモリロン石，カォリン鉱 物（ナクライト，デッカイト，カオりシイト，八ロイ サイト $\left(2 \mathrm{H}_{2} \mathrm{O}\right.$ と $\left.4 \mathrm{H}_{2} \mathrm{O}\right)$, 心゙ーマイト, ギプス石, ダ イアスポア，酸化鉄，水酸化鉄，酸化チタンなに゙が問 題である。これらの生成條件は，原岩又は原鉣物の性 質, 媒質の性質, 温度, 圧力, 時間等!こよつて支配さ れるが，その手懸りとなる 2,3 新しい実験が試みら れた。

岩として前者では酸化鉄で赤く污されたカオリン粘土 後者では酸化鉄，酸化チタン，水酸化アルミニウム存 生じている。チタンの濃集している部分では最高 $\mathrm{TiO}_{2}$

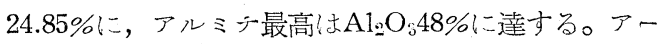
カンスのボーキサイト鉱床はここから界の約 $30 \%$ を 産出しているものであつて，上部潮新統に属する鉱床 で，白型紀の霞石閃長岩が風化によつて地下水面準以 上の部分に生成されている。現地残留型，現地砅型， 漂砂砅型などに分類され, 夫々厚さ数 $10^{\prime}$, 密接に相伴 う。鉣石はギプス石の小球状集合体を主体としてい る。有名なヂョージャのカオリン鉱床は結晶片岩堂 盤とする白㱯紀のカオリンの厚い層苍主とするもので 有力なカオリン資源として古来開発されている。ミン゙ リー州の高攀土質粘土はオルドヴィス紀の石灰岩の風 化面を被稪して生じたるので，心゙ーマイトとダイアス ポアを主とするものである。結局，他の類似鈗床の場 合も併せて鉱物組合せを整理して見ると，時代の比較 的古いものでは多アスポアーと心゙ーマイトを主とし 比較的時代の新しいものではカオリン，心゙ーマイト，
ダイアスポアは $2,0001 \mathrm{bs}$ 以下 $300^{\circ} \mathrm{C}$ 以下では生成され ないこと，約 $400^{\circ} \mathrm{C}$ 以上では，分アスポアは不安定 となつて新たに Mullite存生ずることなどが明かにさ れた。文鉱石の観察によつてダイアスポアの一部が珪 化作用によつてカオリンとなつている例も指摘され た。ハロイサイト $\left(2 \mathrm{H}_{2} \mathrm{O}\right.$ 含む $)$ とハロイサイト $\left(4 \mathrm{H}_{2} \mathrm{O}\right.$ を含むもの)との安定曲線は恰度 $\mathrm{H}_{2} \mathrm{O}$ の尞発曲線と一 致して抢り，水の多いカオリン采結晶の生成條件掠空 気などの湿度に支配され得ることを示している。

diasporeは高温でないと生じない様に見えるが実は モンモりロテイトやカオリティトのコロイド状粘土か らも生成されち。例えばミン゙リー州の高攀土粘土の場 合はそれであつて，多孔質のボーギサイトの球状体は 腐植産に二よ方珪酸分の溶脱在物語つている。

British Columbia の粘上はその D.T.A. 曲線少全 く不規則であるが，Mackenzieによつて行われたFe $\mathrm{O}_{3} \cdot \mathrm{H}_{\mathrm{g}} \mathrm{O}$ の生成條件に関寸石研究結果亡照合して見当 と，種々の異つた條件下で生じた粘土の混合物なる可 能性が多い。

(岩 生) 


\section{摘錄}

\section{探 鉱” 探 炭}

\section{1) クラッシヤと発破, どちらが 岩石破碎に有勏か}

(Fred C. Bond: Which is the More Efficient Rock Breaker? ; Engineering and Mining Journal, January 1954, Page 82.)

クラッシヤと発破，に゙ちらが岩石破砕に有効か子決め る事は大変困難な事である。何故なれば岩石破砕におけ る機俄的効率の絶対值の決め方が末だ定説になつていな いからである。勿論, 種々異るクラッシャの破砕効率を 比較したものはあるが，これは $1 \%$ 以下から50\%以上と いう様に変化が甚しいので，もしこのうちの小さい力の 値をとれば機械による破砕より発破の方が有効というこ とになる。

最近米国鉱山局より発刊された報告書に, Minnesota 州の Mesabi Range の Taconite 鉄鉣床で一定の條 件下で発破を行ない，この粒度分布をしらへた事が出て いるがこれによれば比較が出来る。すなわちこの試験 は $1 \mathrm{t}$ 当り $45 \%$ semigelatin dynamite $0.233 \mathrm{lb}$ 使 用して 25cub. yd. の岩石を破砕したが，この全量の $80 \%$ は $2.75 \mathrm{ft}$ (839,000micron) の四角な孔を通過寸 る。この発破によつて出来た大塊は22個でこの量は全体、 の40\%にあたるがその大きさは下表に示す如くである。

\begin{tabular}{|c|c|c|c|c|}
\hline 寸 & 法 & A & B & $\mathrm{C}$ \\
\hline & & $\begin{array}{l}4.48 \\
1.63\end{array}$ & $\begin{array}{l}2.75 \\
1.00\end{array}$ & $\begin{array}{l}1.76 \\
0.64\end{array}$ \\
\hline
\end{tabular}

ただし $\mathrm{A}$ は最大寸法, $\mathrm{B} は \mathrm{~A} に$ 直角な辺の最大寸法, CはA及び $\mathrm{B}$ に垂直な辺の最大寸法を示している。

使用した dynamiteのエネルギーは900ft-tons $(0.678$ $\mathrm{kWh}) / 1 \mathrm{~b}$ であるから破砕量 $1 \mathrm{t}$ 当りの任事量Wは 0.158 kWh になる。そこで Bond 氏が示した次の式によつて 仕事指数 $W_{i}$ を計算すると $W_{i}=1.45$ となる。

$$
W_{i}=W\left(\frac{\sqrt{F}}{\sqrt{ } F^{2}-\sqrt{P}}\right) \sqrt{\frac{P}{100}} .
$$

但し $W_{i}$ : 仕事指数…(理論的に無限大の給鉣の size

1) U.S. Bureau of Mines, Report of Investigation 4918 Vernon C. Daris : "Taconite Frogmentation" (June 1953) Fig,97, Fig,119, Table 10,

2) Peele : Mining Engineer's Handbook $(5-16)$

3) Fred C. Bond : The Third Theory of Communication, Trans. AIME Vo1. 193.p (484) (Mining Engineering, May, 1952)
80\% は 100Micron の孔を通す様にするに要するkWh) (kWh/ton)

$$
\begin{aligned}
& F: 80 \% \text { 通過給鉱量の大きさ (Micron) } \\
& P: 80 \% \text { 通過座出物の大きさ } \\
& W: \text { 破矺量 ton 当り仕事量 }(\mathrm{kWh})
\end{aligned}
$$

又この仕事指数はさきに示したデータからも計算出来る のでこれによつて計算すると13.5になる。両者の平均を、 とると発破による仕事指数は 14.0 という事になる。

さて,この Taconite Ore 存機械によつて破砕する時 の仕事量を motor の大力によつてみると, 勿論各場所 によつて変化はあるがえの仕事指数は 16.0 になる。今 motor のベアリングや motor の摩擦等を考えに入れて これを叙上の数值から差引けばこの指数は発破の場合と ほぼ等しくなる。

この指数は Bond 氏の The Third Theory によれ ば寨験的に簡単に決定出来るが，この指数によつて種々 の岩石量に対する装薬量も決められるし，掘進速度はこ れに逆比例すると考えられ， bit の消耗量は正比例して 増すと考えられるが正確な関係は未だ得られていない。

size を小さくしようとする場合は現在クラッシャが 設備されている場合は発破によるより安い。何故ならば 同じ $\mathrm{kWh}$ ならコストがクラッシャの方が安いからであ る。他に呀孔費やクラッシャの維持費を考える場合はク ラッシャの方が更に有利になる。しかし，発破で細かく してやれば新しくクラッシャを設置する必要がなくなり 起業費を節約卞る事加出来る。

岩石破砕の機㑘効率の絶体值は未だはつきりとは判つ ていない。しかし，とんなにうまく計画された発破でも その効率存 $1 \%$ 以下にする事は困難であるから, 明らか に高い值をとるものであろう。(田中)

\section{2) Grangesberg 鉱山（スウエ 一デン）の探鉱法}

Stoping at Grangesberg. (Mine \& Quarry

Engineering, Nov. 1953, pp 410〜415)

Grangesberg 鉣山はスウェーデン中部にあり，鉄鉱 石を採掘している。終戦時の 1 工当り出鉱量は $7.5 \mathrm{t}$, 現 在はその約 3 倍に増加している。

釷体の主要部は約 $100 \mathrm{~m}$, 長さ約 $1.5 \mathrm{~km}$, 傾斜 $65^{\circ} \sim$ $70^{\circ} \mathrm{E}$ で, 1550 年頃から露天採鉣法で採掘が始められた お゙，1905年頃, 垂直矩形立坑を 2 本開ざくし坑内採掘に 移行した。最初シュリンケージ法を用い150mレベル迄 採掘を行つたが，次第に上盤の支持が困難となつて来た 


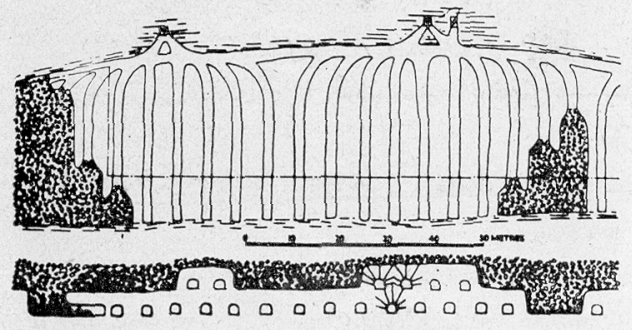

第 1 図

ため中段ケービング法に変えられた。今日迄このう法で 採掘しているが新しい採鉣知識，鉱山機械がその間に応 用され，幾多の修正がなされている。

1945 年頃汔は「シュートローディング」による中段 ケービング法を行つていた。すなわち第1眓の様に中段 を約 $5 \mathrm{~m}$ の垂直閒隔で設け，このキ段の各々から横坑を 1 本下盤に沿つて掘進し, 横坑から多くの平行立大を上 盤迄掘進した。立入の加背は $2 \mathrm{~m} \times 2 \mathrm{~m}$ ，水平間隔は $10 \mathrm{~m}$ とし, 立入連絡用に $4 \mathrm{~m}$ 間隔の副横坑夲切る。採掘は立 入の上盤側から下盤側に後退して行く様に行なう。穿孔 はコラムに取付けたハンマー型さく岩機で呞形に行ない 爆破後シュートから鉱車に積入も。1ラウンドで $1 \mathrm{~m}$ 後 退する。

その後TCビットを植えた鑚, 軽量さく岩機, エャレ ッグを組合せたスウェーデン式穿孔方法啋用して，コ ラム,ジャンボーの様な重装備を廃棄し, 又人員支減少 、し仕事に融通性苍持たせた。又今迄の開坑方式の内, 立 入の加背を巾 $1.9 \mathrm{~m}$, 高さ $2.2 \mathrm{~m}$ し, 副横坑は掘進しな い。採掘は以前と同様に立入の上盤側から下盤側に後退 しながら行ない，呀孔も扇形に行なう。使用さく岩機は Atlas Diesel Co. の RH-656W 型空気さく岩機で, 重 量 $21 \mathrm{~kg}$ ，ピストン直径 $65 \mathrm{~mm}$ ，ストローク $55 \mathrm{~mm}$, 又 エヤレッグは Atlas Diesel Co.の BMK-81A2 型で, フィード長 $1,300 \mathrm{~mm}$ ，ピストン直径 $57 \mathrm{~mm}$ である。鑚 は Sandvik Co. の六角中空鋼で先端に TCチップを

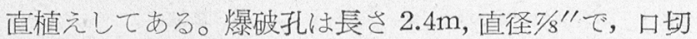
り鑚，接ざ鑚は便用しなかつた。しかしどうしても短い 鑚を使わねばならぬ所では $1.6 \mathrm{~m}$ の鑚を用いた。しかし 上の中段汽の釷石を一度に取执うには $6 \mathrm{~m}$ の爆破孔を掘 らねばならない事がわかつた。しかし狭い立大内で一度 に6 $\mathrm{m}$ の爆破孔は穿孔出来ない。鑚を接ざ足して行うと しても穿孔時間が大となるので Sandvik Co.で「可撓 性」平鑚を製作した。これは断面が矩形で先端にTC东 ップを植え, 中空で容易に曲げられるので, 狭い立入内 でも先端を爆破孔中に差込さ事が出来る。この可撓性平 鑚を用い，今迄よりも長い穿孔が出来る様になつた。

各ラウンドの爆破孔数は 10〜20 孔，爆薬はダイテー イトで鉱山附属の火薬工場で作つたものである。文点火
は普通の導火線で行つている。

破研鉣石の積込はAtlas LM-30 型転倒バケットロー ダーで行う。これは容量約 $0.11 \mathrm{~m}^{3}$ で圧縮空気羽根車型

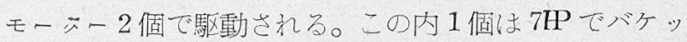
卜運転及び旋回用，他の 1 個は $6 \mathrm{P}$ で車輪 駆動用であ る。全長はバケットを破䂽鉱石中に突込んだ位置で $2 \mathrm{~m}$ ， 積込可能の内は $2.2 \mathrm{~m}$, 又バるットの自動回転装置があ る。鉣車は容量 $2 \mathrm{t} の$ 縦空け鉱車であるが，このローダ ーで 2 分以内に積込める。積迀みを終つた鉱車は軌間 $75 \mathrm{~cm}$ ，勾配 $1 / 150$ の $10 \mathrm{~kg}$ レール上总手押し運搬!， 鉱石漏斗に鉣石范落す。

中段ケージングに彷事する従業員は 3 人 1 組となつて いて 8 組以下の人数の従業員か 1 人の監督の指揮下にあ る。賃金は出鉱量請負で，この場合硑混入の程度は関係 しない。学動時間は 1 週 40 時閒，港揚は 1 日 17 時間運 転する。中段ケージングの従業員は呀孔，爆破，積込等 すハての作業を行い， 又この外にェヤレッグ，軽量さく 岩機学使用古る坑道掘進も受持つ。坑道掘進の穿孔は Vーカット又はバーンカットで約 30 孔等孔する。中段横 坑の坑道掘進では Atlas LM-30 型ローダー, 2 t 綎空

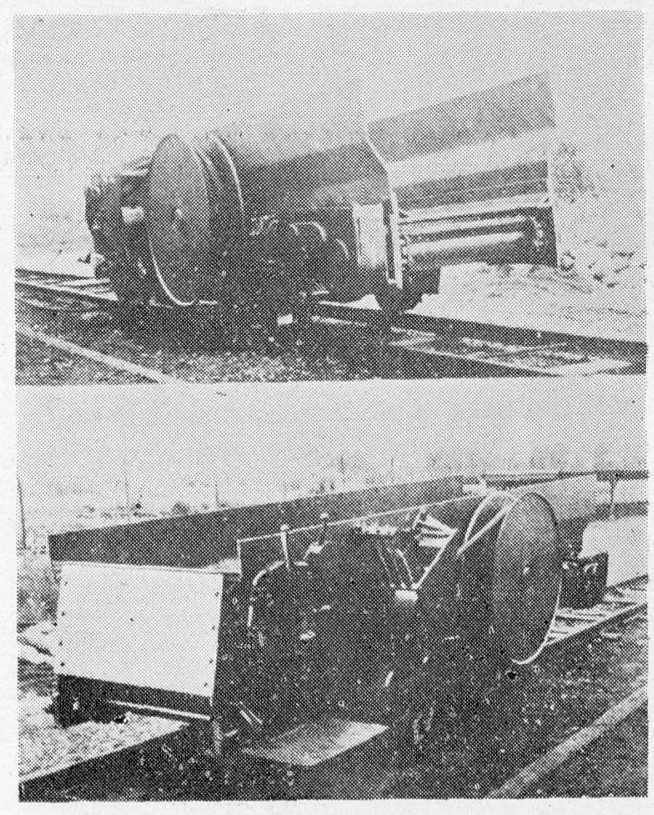

第 2 図

け鉣車な使う。主要坑道掘進では Atlas LM-100型，ハ ケット容量 $0.2 \mathrm{~m}^{3}$ の大型ローダーを用いる。これは $14 \mathrm{H}$ のバケットモーヌー及び 11 P の駆動モーダーを持ち， 全長 $2.55 \mathrm{~m}$ である。そして高さが $2.52 \mathrm{~m}$ の歫道で積 込が出来る。

1952 年度の平均坑道掘進長は $1.47 \mathrm{~m} /$ 二であるが， 1953 年中には $1.75 \mathrm{~m} /$ 工以上に到達する見迄である。更 に従業員を減らすために, 手押し運搬の代りにレール上 
を圧縮空気力で走るシャットルカー定現在試験してい る。これは第 2 図の様にAtlas Diesel Co. 製のもので 容量 $5 t$ ， ピストン型它気モーター1個が動力用に取付け てある。

切羽における全従業員の 1 工当りの出鉱量は，1945年 度は23t，現在 (1953年)は85tに増加した。又1946年 と 1952 年のシュート積込の割合は $65.6 \%$ か $5.7 \%$ に下 りこれに反し機械積込の割合は $22.8 \%$ か $91.7 \%$ に増 加している。(大等敬男)

\section{3）六面体ダイヤモンドの定位椬込み}

Eugene P. Pfleider: Orientation of Cube Diamond in Drill Bits (Mining Engineering Oct. 53 pp 998)

筆者は先にボーリングビットのダイヤモンド植込に当 つては，高硬度の結晶面を利用した方方有利である事を 発表したが (Mining Engireering Feb 1952) 其後現 場や研究所等で行われた比較試験においても, 不規則方 向に植込んだビットに比し，定位植込みビットのうが掘 進早く摩䊈量も半分以下である事が明らかとなり，最近 或るビット製作者は以上の結果による定位植达法を作業 者に訓練し始めた。

先報告には結晶学上ダイヤモンドの硬度差について述 べ，主として八面体の定位植込ビットの赛験について報 告したが，引続き六面体結晶につき同じ装置を用い，1 カラット当り10個の六面体ダイヤモンドを植込んだ 7 個 のビットについて実験を行つだ。

今回の定位は 5 方向である。すなわち

1一六面体の隅角在尖端とし切削方向に向いた位置
(正角と称す)。(ビット番号 $\mathrm{M}-11, \mathrm{M}-15$ )

2- 一同じく六面体隅角が負角の位置 $(\mathrm{M}-14)$

3一六角体の陵線が切削方向に直角でかつ垂直の位 置 $(\mathrm{M}-12)$

4-一同しく陵線が切削方向に平行でかつ垂直の位置 ( $\mathrm{M}-13)$

$5-3$ と同様である加正危の位置（M-16，M-17)

以上各ビットの成績は次の通りである。すなわち第一 定位は前の八面体結晶の笑験結果から最優秀の成績が期 待されたが，実際は異なり，尖端が直ぐ摩隇して平らに なり，穿孔速度起減少せしめた。しかして或る压力に達 すると 1〜2 のダイヤモンドの尖端は破壤せられ，その 為他のダイャモンドをも破壞する因となり，ての短時間 は切削速度を大とする結果となつた。 M-11，M-15ビッ 卜共大体似た経過をとり総穿孔長も18.7及び15.3呎であ つた。

第三定位の M-12 は十二面譬開面の弱線を除けば大体 強い位置であるが早期に破壤が起り，穿孔長11.5吹附近 で益々破壇度が大きくなり，ついで摩隇が大きくなつて 結局 M-11，M-15 と余り変らない総穿孔長を示した。

第四定位は早くから破壞が起りその為時々大きい穿孔 速度芷示したが摩隇も激しく結局 M-15 とほとんど同し 穿孔長をえた。

第二定位は最初の1吹で破壇が起り前回実験の結論堂 益々確認する結果となつた。

第五定位の M-16，M-17はM-12 と似ているが唯十二 面体面に対しては $22^{\circ}$ 切削方向に負角を与えただけであ る。すなわち六面体に詨しては正角の位置である。その 結果は構造的に最も強固な方向となり，十二面体の最も

第1表 ダイヤモンド摩耗量

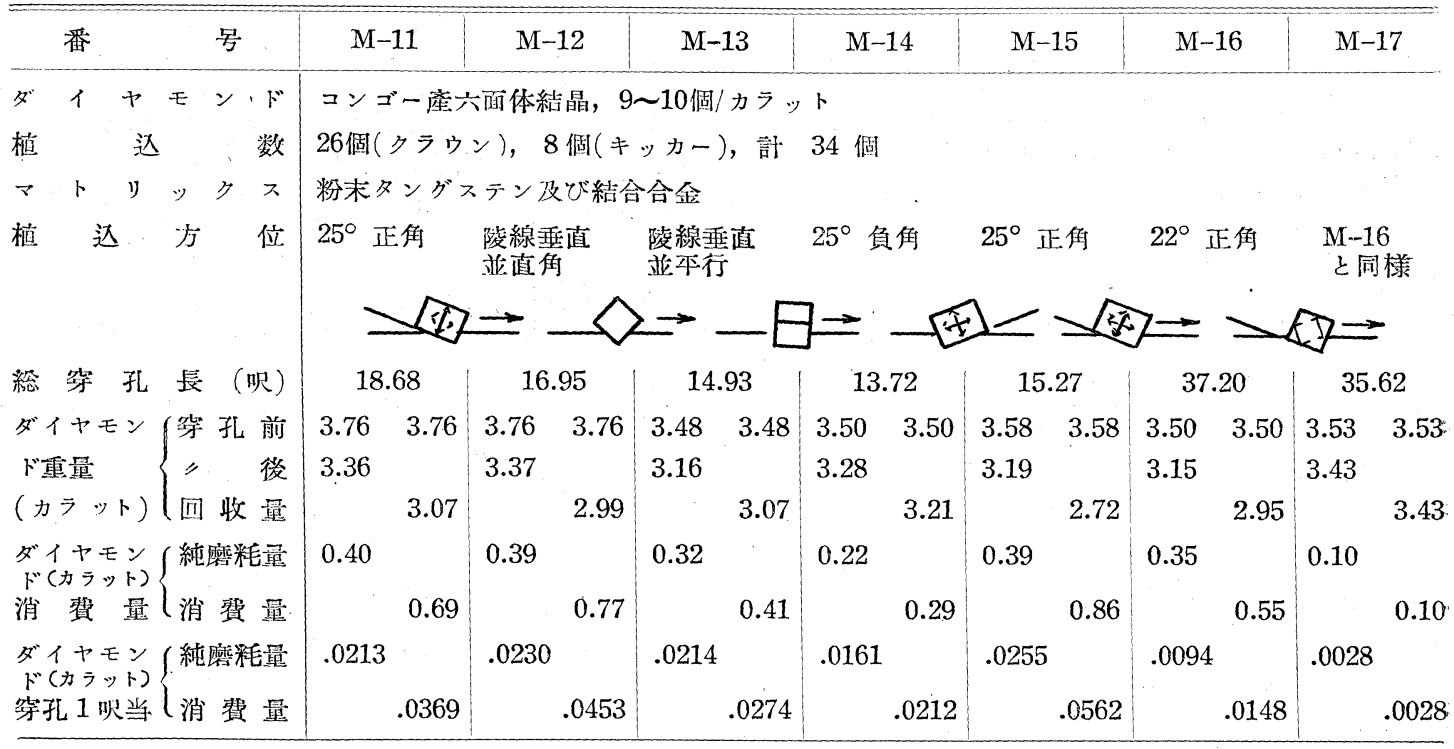


第 2 表 コンゴ產ダイヤモンドの穿孔成績比較

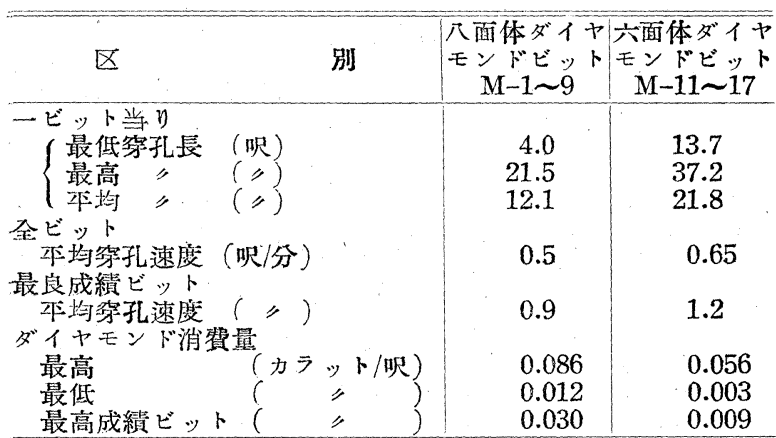

被害である。ウラン生産の重要性から Colorado 高原地域の鉱山労働都はラドンガスに曝され Bureau of Mines 及び Public Health Service の 予備的調查によつてもこの地带の鉣山におら!ては 何礼も空気 $1 l$ 中に40マイクロ・マイクロキュリ 一位検出されている。ラドン?坑内壁面又は採鉱 作業中に空気中に拡散し，障害の原因は放射性 ドンとこれより出来る $\operatorname{RaA}, \operatorname{RaC}$ に基くもので, これが強力なアルファ粒子を放射し細胞を侵す。 48のウラン鉱山坑内岱気の試料 132 について見る とラドンの中数値は 3,100 と云う值を示している。 しかしウランのない鉙山でもこの現象はある様

硬い方向に摩滅が起る為, 一番寿命が永かつた。すなわ ち他のビットの13.7〜 18.7呎に対し何れも2 倍近い37.2， 35.6 呎の総穿孔長を示し穿孔速度及び摩粍状況も M-16 が最後に多少乱䏓の除けば非常に平均しており最低 0.3〜0.5炚/分の穿孔速度を維持している。

各ビットの摩粍量は第 1表の通りであつて M-16, M17 ビットか最も少なく，もし M-16ビットの穿孔を35呎 で止めれば，同ビットの摩粍量も M-17程度に少なくな る䈱である。

当実験と前回の結果とを比較すればコンゴ座工業用ダ イヤモンドについては六面体結晶の方が同質，同じ夫き さの八面体結晶より，穿孔成績が良い。（第 2 表参照）

結論として，（1）八面体結晶に比し六面体の方がビッ 卜寿命永く，ダイヤモンド消費量が少ない。

（2）六面体陵線において切削すれば強勒である。

（3）最良の定位は陵線虎切削方向に 20〜 $25^{\circ}$ 向け， (正角)六面体面が 20 250 の解度を示し，十二面体面に ついては負角ななす場合である。この定位では消費量は 警く程少なく，しかも再植込の為に8つの異つた陵線を 利用与る事が出来る。

(川崎)

\section{4）米国鉱業の保安衞生}

Ash, S. H., Minera (Industry-Health and Safety. Min. Eng., Feb. 1954, pp195 196) 本交は米国鉱業の年次評論であるが，米国は1910年の 鉱産額20億ドルに対し1950年において 120 億ドルと増加 し，これに対し死亡は1911年の3,539名から1951年の974 名と減少し各部門に亘つて保安の進歩は著しい。しかし 電気及びディーゼル施設に関しては適正を欠くと新しい 危㫪が起り得る。

衞 生一墝内に抢けるディーぜル施設の増加は顕著 で, 最近17年間に34の坑道開さくにこれが用いられ石炭 以外の77の鉣山で便用される様になり大規模の露天掘か ら細胍掘り坑内にまで行渡つた。したがつて通気の問題 加ら坑道断面がくなり保安的考慮から正常な使用法を 実施している鉙山に括いてはこれに関した災害は起つて いない。

次に珪肺又に湖疾患についていさこ数年間に認識が梁 ぬられ子備対策に大きな進歩が見られるに至つた。次に 最近問題な提供しているのはウラン鈗の採掘に伴ら人体
で, Arizona の銅山では 8〜300 を示し Idaho の銀鉛鉣 山, Montana の銅山の試錐孔からも検出され, Coloradoの金属山, 粘土山, 石炭山加検出されている。 ドンより生ずる $\mathrm{RaA}, \mathrm{RaB}, \mathrm{RaC}, \mathrm{RaC}^{\prime}$ はがス状でな く数分の半減期であるがこれらの大部分は吸引されて肺 を侵す。Publie Health Service ではこれらの許容限界 量を一応 100 と想定している。対策としては硅肺におけ ると同しく坑内通気によつて行う。

吊りボルト法一この方法は最近広く普及し過去 5 カ 年におけてい坑道掘進にも使用されている。この使用は 機㑘化の伸展によつて従来の坑木の存在が障害となるこ とから研究が進み，現在は落盤防止に大きな効果党与元 ている。1951年10月31日現在㞸鉱において 639 金属及び 非金属鉱山において 140 が使用している。なお経験に二基 いてこの方法の使用目的を考えると

1. 天盤のゆるい部分在吊つて維持する。

2. 早期に岩盤党固めて变形を少なくし弾性の範囲内 に止める様にする。

3. 圧縮, 剪断応力に対し抵抗を増してアーチを強化 させる。

ことになる。なお金属鉱山では切羽にこの方法を使用す ること岂始めた。勿論現在は萠芽期に過ぎないが将来性 は計り切れない。次に落盤による死亡統計は次の通りで ある。(1953年12月現在)

\begin{tabular}{c|c|c|c}
\hline 年 次 & 死亡件数 & $\begin{array}{c}\text { 坑 内 稼 動 } \\
1,000,000 \text { 人時当 }\end{array}$ & $\begin{array}{c}\text { 坑 内 稼 動 } \\
1,000,000 t \text { 当 }\end{array}$ \\
\hline 10年平均 & 467 & 0.74 & 1.04 \\
$(1938-1947)$ & 434 & 0.77 & 0.95 \\
1948 & 259 & 0.65 & 0.78 \\
1949 & 259 & 0.68 & 0.76 \\
1950 & 300 & 0.63 & 0.72 \\
1951 & 298 & 0.57 & 0.65 \\
1952 & 231 & 0.58 & 0.62 \\
1953 & 197 & & \\
(1月-11月) & & & \\
\hline
\end{tabular}

調査研究一-1953年 9 月に多くの電気工作物加認可さ れたが米国の坑内には外国の設諳になるものが次第に多 く用いられる様になつた。しかし外国の施設は使用條件 も標準も米国と異なることが多いので注意を要するとこ ろである。殊に電気工作物でも下ロリ一電車の如きは感 電之火災，爆登の主要原因となるので，鎕業に扎いては 裸線を必要とする様な運搬法は将来これに代るすの在用 
いて㯰換えることが考えられてよい。又採鉣法が新しく なり施設が進歩するにしたがつて坑内切羽と附帯個所の 照眀が改良されることが期待されてよい。

災 害—-1953年に発生した主要災害（爆発）は2 件 であるが，これらは何れも充分予防し得るむのであつて 管理の良否が問題となる。第 1 の例はUtah の露天掘で 起つたもので死亡 8 名, 軽傷 3 名，火傷 2 名，飛石 1 名 で残杜を穿孔し発破をかけたときに爆発した。証拠によ ると火焰は地表の昇降室から起つて坑内に入り全坑に及 んで扣りバケットェレベーターの原動機の過熱と推定さ れたものである。第 2 例はO'Brien鉱山の炭塵爆発で当 日 2 名の発破係が黒色火薬の爆発によつて死亡，これが 午後 4 時であり同日午後 6 時に死体が収容された。その 後午後 9 時に爆発調査のために大坑した 5 名の中 3 名は 一酸化炭素中毒で死亡し, 残り 2 名は難をのがれて昇坑 したが内 1 名は 3 日大院したと云う災害であつた。

死亡率—1953年は座業各部門に亘つて前年に比較し て何れも死亡率が減少し炭鉱に沶いても（1953年 1 月 1 日〜12月 1 日） 100 万人時当り 0.78 となつている。この 傾向は27年間について調へてみても同様で漸減の傾向が あり将来更に減少することが期待される。米国において は石炭鉣山と金属鉱山及び採石山を比較して何れが安全 であるかの論議がよく行われるが，環境分析の結果によ ると金属山の方が危険が多いにもかかわらず実際は炭鉱 の方が事故が多い。この差異の原因について座業各方面 の意向を綜合すると主として管理の問題であり金属鈜山 においてはこれがよく行きとどいており，更に石炭鉣山 に見られる請負制度が行われていないことにも原因して いると見ている。しかし鉱業に㧊いては次第に安全な方 法が採用されて来ると共に保安教育が災害予防に著しい 効果のあることも認識され，他座業の災害と比較検討し なおかつ災害防止は労衝者が中心であることを認識する 様になつた。

(中野)

\section{選 鉱・選 炭}

\section{5）1953年度における選鉱の進步 (その 2 )}

Donald W. Scott: Developments in Minerals Beneficiation—Annual Review 1953. (Mining Engineering, Feb. 1954, 166-173)

$$
\text { 一前号よりつづく— }
$$

\section{IV 箶分. 分級}

\section{1. スクリーン}

28〜35mesh 程度の細粒篩分用として数個所の工場で 採用された洗深スクリーンの成績は，充分見込のあるも のであつた。このスクリーンの特色は，（1）ステンレス
スティールの穊面，(2)禾ールの入つた仕切り箱，（3) 洗滌用リパルピング・トラフ，(4)標準より速い速度と いつた点にある。

電熱スクリーンは特殊用途向として一段と機械的改良. が加えられ，熱を節枠になるへくく伝えずに大部分篩面自 体に保つように工夫が施された。

Mesabi 鉄鉱地带にいわゆるWobblyスクリーンを使 用した工場方建設された。このスクリーンは昔のロー ル・グリズリ (live-roll grizzly) に似たもので，ロー ルの断面が棈円形になつている点が変つている。

もう一つ1953年に実用化されたものに Bergstrom ス クリーンがある。このスクリーンの節面は鋼板にゴムを゙ 焼付けした後パンテした特殊のもので，銅板の孔はゴム の扎よりもやや大きめになつているため，磨耗を防ぎ， かつ目詰りを防止するといわれている。

\section{2. 湿式サイクロン}

湿式サイクロンはこの年に相当の伸展を示し，デステ イミングの分野ではその地歩を確立したように見える。 さらにレークあるいはスパイラル分級機の領域に対して も，特に二次粉碎回路用として侵大しつつある。

1953 年には湿式サイクロンは南アフリカの Rand Leases Gold Mining Co. 抢よび米国ノース・カロラ イテ州の Tungsten Mining Corp.におおて採用され また Mesabi地方のタコナイト2工場をの他においても 試験されている。一般的な傾向としては，耐磨耗性をよ くするために比較的軟かいゴム・ラィニングを使用する ようになり，フィードの流大圧力む低目にする方向一進 んでいるようである。サイクロンの選択はそれぞれの工 場の特異性に支配されることは論を俟たないが, 現在試 験中の工場は充分多数にのぼつており，サイクロンの長 所短所を明確に決定士るのは難事ではないと思われる。

\section{3. 節分または分級効率}

特に閉回路粉碎におういては，スクリーンや分級機にお。 ける良好な分離が重要な意義を有するという見地から， 節分または分級効率を決定寸る標準的な方法を定めるへ きだと考えられる。ここに一つ提示された方法は，絧下 またはオーバフロー産物の絧下積算粒度分布曲線と, 網 上または搔上産物（ア、ンダフロー）の網上積算粒度分布 曲線とを粒度に関してプロットし, 両曲線の交点に抢け る粒度を分離粒度，交点における絧下積算重量\%を穊分 または分級效率とする，というのである。

\section{$\mathrm{V}$ 脫水}

\section{1. フィルター}

固体一液体の分離すなわち脱水・脱液の分野は, いつ もより活況を呈した。反転型の水平パン・フィルターが ミズーリ州の St. Joseph Lead Co. の工場に採用され 
またディスク・フィルターの処理範囲を拡張するための 穖械的摫䢁法がいくらか進歩を見せた。また半連続的〉 イルター・プレスが試験の結果認められて, Mineral Engineering Co. の Salt Lake City ヌングステン工場 に採用された。これは（1)プレスを開き，(2)>レー ムを動かして空にし，(3)新しいフレーム存戾し，(4) 加圧下で再び閉じるという仕事考す心て機械力で行うま ので，1サイクルの終了から次のサイクルの開始までの 不稼働時間 (down time) 加 1〜3 分(稼働時間 on stream timeに対し 4 ～ $8 \%$ 程度) に過ぎないと云う。

2. 瀘布 (filter cloth)

ポリエテレンの単繊維もしくは 3〜5 プライの撚つた ๖のが濾布に織りれるようになつた。ポリエチレンは 酸, アルカリ，無機塩類および大部分の有機溶偊に侵さ れず，またその弾性的な性質はヶークの剝脱にもきわめ て好ましいものと云われている。

むつかしい濾過の問題に対して，サランあるいはナイ ロンの濾布が場合により回答を与えると考えられるので あるが，適当な濾布を選択する際には，好理される粒子 の粒度などよりもつと遥かに複雑・不明確な問題が存在 することは明らかである。その意味で本年 2 月の AIME 年次総会に予定されている Frank T. Weems の“A Practical Approach to the Selection of Filtration Media”という論文は注目される。な抢濾過速度を増大 させるために添加する特殊の試薬が最近紹介されてい る。

\section{VI 浮 選}

\section{1. 基礎研究}

浮選に関する基礎的な研究はは本年度は整く程貧弱であ つた。Hukki とVartiainenは脂肪酸の捕収力が炭化水 素鎻の不飽和度と共に増加することを示した。 Gaudin そ Cole はオレイン酸, リノール酸, リノレン酸の二重

1) Tall Oil に含まれる脂肪酸の酸化鈆物に対する烳收効果につい て [摘錄〕(日本鉱業会誌, 昭和28年11月，517-518頁)

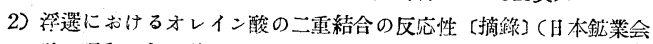
誌, 昭和28年 7 月, 273-274頁)

3) カルシウムミナトリウムの黄鉄鉱への吸着[摘錄](日本鉱業会誌, 昭和28年 5 月, $175-177$ 頁)

4) J. Leja and J. H. Schulman: Flotation Theory: Molecular Interactions Between Frothers and Collectors at Solid-Liquid-Air Interfaces. (Mining Engineering, Feb. 1954, 221-228)

5) 鉄鉱のアミン浮選に抋ける没粉類の抑制作用について〔摘錄〕(日 本鉱業会誌, 昭和 29 年 3 月, 123-125面）

6) G. E. Atwood and D. J. Bourne : Process Development and Practice of the Potash Division of the Duval Sulphur and Potash Co. (Mining Englneering, Nov. 19.53, 1099-1104)

7) (訳者陆) 別の文献 (Metals Will Use More Chemicals, Chemical Engineering, Jan. 1954，379）によれは表中起泡

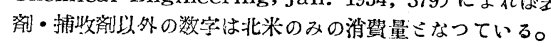

結合の酸化は浮選中には起らないこと,ならびにこれら の浮選剤の捕収性は二重結合の酸化以外の或種の性質に 関係するものであることを示した。Gandin とCharles は放射性追跡子を用いて Ca および $\mathrm{Na}$ イオンの黄鉄鉱 への吸着を測定し，同じ $\mathrm{pH} に$ に扎て Ca イォンは Na イオンよりも一層容易に吸着されることを示した。この 事実は黄鉄鉣が何故石灰によつて容易に抑制されるかな 説明するのに役立つ。

MIT は次のことを研究中である。(1)放射性追跡子 でマークした試薬を捕収剤, 活性剤および抑制剤として 使用した平衡吸着の研究，(2)鉱物一溶液界面における 陰イオンと陽イオンの不対称分布の結果生ずる表面電荷 の研究，(3)水中に抢ける粒子の運動のもたらす電気的 効果の研究（鉣物表面に近接した溶液内におけ方電気的 二重層の組成について資料克得るため)，（4）鉱物一液 体一気体間の 3 界面における揮登性捕収剂の吸着による これら 3 相の系の調査研究。

英国ケンブリッジ大学の J. Leja と J.H. Schulman は固体一液体一気体界面に抢ける起泡剂々捕収剤の間の 分子間相互作用に関する論文を発表した。パリのSchool of. Mines and Metallurgy $の$ M. Rey $と$ P. Raffinot は酸化した亞鉿鉣の浮選の理論と実際について今月の AIME で発表する予定である。U.S. Bureau of Mines RI 4990 には比色法によつて水中におけるパインオイル を定量する方法が記載されている。Chang 等は実験空 試験におけるスライムと再現性の問題を軽減するために 工夫儿た $50 \mathrm{~g}$ 空気吹込式浮選機について記述している。

\section{2. 浮選剂}

ニタ大学冾金学教室ではスライムの凝析に関す当研究 を行い，特殊の有機化合物によつてネライムの浮游性お よび瑯降と濾過の速度が改善出来ることを示した。Duval Sulphur and Potash Co.のカリ鉣山では, 特別に悪 い粘土質スライムの問題が存在したのであるが General mills 製の Guartec という特殊の試薬によつて, 浮選 存成功に導いた。Guartecは陽イオン性捕収剤の添加 に先立つて粘土鉣物の構造間阷を充填閉塞し, その結果 捕収剤の消費量を減じ選択性を向上せしめたのである。

1953年にはAmerican Cyanamid Co.は Aerofloc 凝析剤を登売した。これは普通使用される凝析剤でうま く行かなかつたような場合に, 微粒子奬濁液の沈降之濾 過の速度を高め乞のにきわめて有効であるという評判で ある。また同社の発売した Aeromine 2026 と云う試薬 は石英抢よび珪酸塩釷物に対する陽イオン性捕収剤であ る。

1953 年 9 月ペンシルバニア州 Pacona Summit で開 かれた Chemical Market Research Association の会 合で，金属工業関係で消費あるいは生産される化学製品 
の傾向についての研究会が催されたのであるが，その席 上 Dow Chemical Co. の R. W. Forsythe は浮選剤 の消費状況を論じた。それによると現在の世界の年消費 量は次表の如くである。

\begin{tabular}{|c|c|}
\hline 種 & $\mathrm{t} /$ 年 \\
\hline 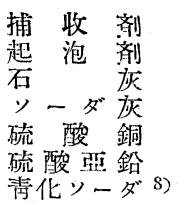 & $\begin{array}{r}13,600 \\
11,200 \\
231,000 \\
33,600 \\
17,700 \\
13,150 \\
4,200\end{array}$ \\
\hline
\end{tabular}

捕収剤 13,600 七 うち $32.8 \%$ は米国で $16.7 \%$ はカナダで消 費され，また起泡剤 11,200 七のうち 57.6 \%は米国，12.5\%は 南米，11.7\%はカナ ダで消費されると云う。浮選剤の市場というのは世界の 非鉄金属の生産と密接な関俰があるので，その市況の傾 向は非鉄金属の生産状況から正確に予報するここが可能 であると同氏は述へている。

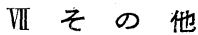

\section{1. 製鍊との関連事項}

1953年における選鉱に関係のある分野での最大の発展 の一つは湿式製鍊技術の進歩である之云つてよかろう。 たしかに選鎕と生産治金 (extractive metallurgy) と の間の境界線は非常にぼんやりしたものになりつつあ る。すなわち，（1）チタン鉄鉣の処理を目的とする Quebec Iron \& Titanium の方法, (2)硫化ニッヶル の粒子之硫化銅の粒子を分離するための International Nickel Co. のマット浮選, (3) Ni, Cli，抢よび Co の硫化鉱その他の金属に対する Sheritt-Gordon 抢よび Chemical Construction Co. の浸出一還元法, (4) $\mathrm{AEC}$ (原子力委員会) の液体一液体抽出抢よびィォン 交換による金属の製鉬，（5）Dorr Co. の流動焙焼 (FluoSolid roasting)などは特に注目に值する新技術 である。

中でもイオン交換の分野では，アイオワ州立大学がこ れによつて稀土類元素を生産する研究を積極的に進めて 抢りまた Permselective membrane というイオン交 換膜（陽イオンのみを通すものと，陰イオンのみを通す ものとの 2 種類加ある) や連綍的イオン交換装置の研究 も実施されてい当。英国の或名研究所は $\mathrm{Au}, \mathrm{Cu}, \mathrm{Zn}$, $\mathrm{Ni}, \mathrm{Ag}$ 抢よびFe 孝含むカナダの複雑鉱をイオン交撸 によつて好理する研究に成功したし，富洲の McNeil, Swinton および Weiss は大規模の逆流式イオン交換装 置にジグ選鉱の技術存改良して採り入れたのである。

化学工学関係の技術者の援助によつて選鉱および製鍊 は多くの重大な変化を受けていることは疑いない。たし かにこの両者の連罊は一層緊密なものとなり, 離すこと の出来ない様になるのも只う遠い将来であるまいと思う

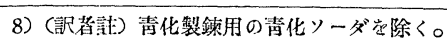

次に団鉣，焼結の分野では粉鉄精鉣の焼結およびノデ ュライジングに対する関心が高まり，また焼結塊の物理 的・化学的試験法を標準化しょうとする動きが見られ た。Noranda Mines Ltd. は硫化鉄精鉱から硫黄と亞 硫酸がスを回収し, 最終産物として酸化鉄焼塊を得る方 法を工業化しようとしている。この方法は焼結條件をコ ントロールすることにより先ず硫黄分の約半分を除去し てコットレルに送りここで単体硫黄を得ると云う点に 興味がある。それから燒結は更に続行され，最後に硫黄 分の低い酸化鉄焼塊を得るのである。

\section{2. 附属設備}

Allen-Sherman-Hoff Pump Co.は新しい Centriseal ポンプを市場に出した。これは固体を処理するた めに完全にゴム・ライニングを施され，しかも sealing water のいらないポンプである。

乾式鉱石運搬の関係では，ストレン・ゲージを使用し たいくつかの新しい棓量装置が新分野を開拓した。これ らはビン・コントローラ，コンベア科量器，トラック・ スケールなどに採用されている。湿式鉱石運般関係では 数種の新型パルプ濃度コントローラが登場した。その中 の一つは放射能を利用したもので, 前代未聞の精度をも つていると云われるが，維持費も前代未聞ではないかる 心配されている。フロリダ州の或る会社は連続的パルプ 科量器を考案したと云われるが，これこそ選鉱技術者が 常に望んでいたものなのである。U.S. Bureau of Mines IC 7663 には重液選鉱工場用重液濃度計の記載がある。 なお運転管理用としての閉回路テレビジョンは将来性が ある。

電気炉で作られる新しい鋼合金（約 $27 \% \mathrm{Cr}, 2.5 \% \mathrm{C}$, 1\%Mn 含む）が嫁洲アデレードの Mason \& Coxに よつて発明された。この合金は Broken Hill 鉱山で浮 選機のインペラーに使用されているという。プラスティ ックスは選釷関係にも無数の用途が考えられるが，特に ゴムと併用される場合, プラスティックスの軽量とゴム の耐磨耗性という両者の利点を同時に活用することが出 来る。タンク，樋，パイプなに゙にこれを応用したものが 用いられている。いずれにしてもプラスティックスは非 常に近い将来，選鉱技術者が普通にもてあそぶ材料とな るであろう。

(今泉)

\section{6）カナダにおけるウラニウム 鉱の選鉱}

A. Thunaes: Recovery of Uranium from Canadian Ores. (Canad. Min. Met. Bulletin, March 1954).

カナダでU鉣物として現在最も重要なものはPitchblende (瀝青ウラン鉣) 及び Uraninite (閃ウラン 
鉱）であるが，その外にも種々のU鉣物方存在し処理方 法は鉣物の種類によつて異なる。処理方法の主体をなす ものは酸又はアル゙カリ浸出による湿式製銶法であるが， 原子爆弾の原料としての莫大な需要に応ずる為には $\mathrm{U}_{3}$ $\mathrm{O}_{8}$ 0.05 0.1\% 程度の低品位のU鉣走処理する必要があ るので，選鉣可能な鉱石はなるへく選鉣して処理鉣量の 増加と処理費の低減を計らなければならない。選鉱法と してはジグスはテーブルによる比重選鉱法, サイクロン を利用する重液選釷法, 浮選法及び電気的選別法があり 鉱石の性質に応じて適当な方法が選ばれる。

比重選鉱法に適するU鉣物は Uraninite, Fergusonite, Euxenite 及び塊状で比重の重いPitchblende で ある。比重選鈗の精鉱品位は $\mathrm{U}_{3} \mathrm{O}_{8} 10 \%$ 以上で穾収率は

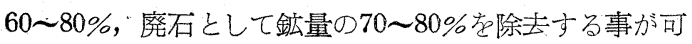
能である。ペグマタイト質の鉱石でU鈗物が粗粒の場合 には比重選鉣の実収率が 80〜90\% に達し原鉣品位か $\mathrm{U}_{3} \mathrm{O}_{8} 0.1 \%$ で採算に乗るものもある。しかし一般にU鉣 物はスライム化する傾向が強いので比重選鉣を行う場合 には破碎磨銗に桠度に注意しなければならない Eldorado Mining and Refining Co. の Port Radium I 場では Pitchblende の一部がジグで容易に回収されて いるが Beaverlodge 地域の Pitchblende のように軽 く脆くしかもその大部分が薄片状灭は他鉱物を被覆する ような状態で産出するものは比重選鉱法に適さない。 Gummite, Carnotite, Uranophane, Torbernite $よ$ うな二次鉣物は比重選鉱に不问きで浸出法により原鉱か らUを直接に回収する。Uranothorite は酸浸出で相当 な実収率が得られるが鉣石の性質によつては比重選鉱も 利く。

Beaverlodge のU 鉱に対してサィクロンによる重液 選鉱の試験が行われているが，この方法は粒度48メッシ ュまで適用可能で廃石の除去率は50\%以上と云われる。 粗粒のU鉣の選別には Lapointe picking beltを 使用する独特な方法もある。Thucolite のような宸化 水美を主成分上寸るU鉱物には浮選法が最適の選鉱法で ある。Euxenite, Fergusonite, Pyrochlore, Ellsworthite, Hatchettolite, Samarskite等 のU鉣物は通常の漫出法老以てしては $\mathrm{Cb}$,Ta及び稀土類のような有価成分存 回收出来ないから，比重選鉣又は浮選 によつて充分に品位を高めた後，加熱 した強酸で浸出觉行うより外に適当な 処理法がない。浮選法はまたUraninite の選鉱にも適用し得る。

Pitchblende, Uraninite, Uranothorite 等は稀硫酸で漫出す当のが最 も普通の処理法であるが，この鉣石中 に方解石只の他の炭酸鉣物が㐫ると硫 酸の使用量が蒿さので予め浮選によつて除去する必要が ある。又 Carnotite や炭酸鉱物点極めて多量に含む Pitchblendeに対しては加熱した炭酸アルカリ溶液で浸
出処理を行うのが普通であるが，この場合は硫化鉣物が 有害なので硫化物として S $0.5 \%$ 以上を含む鈗石にこつい ては予め硫化鉣物を浮選で除去する必要がある。

カナダのウジニウム鉱物 (Geological Survey Circular 194 による)

Pitchblende (瀝青ウラン鉣) 非晶質の閃ウラン鉱, $\mathrm{U}=56.9-82.9 \%$

Uraninite (閃ウラン鉱) UO@, $U=88.2 \%$ ，比重= 9.0-9.7

Uranothorite (ウラノ・トール石) トール石 $\mathrm{ThSiO}_{4}$ の变種で $U$ 兑含むもの。比重 $=4.1, U=10.1 \%$ 以下

Thucolite 又は Thucholite 閃ウラン鉱と炭化水素 の集合体，灰分中に最高 $45 \%$ U学含有する。

Uranophane (ウラフフェン) $\mathrm{Ca}\left(\mathrm{UO}_{2}\right)_{2} \mathrm{Si}_{2} \mathrm{O}_{7} 6 \mathrm{H}_{2} \mathrm{O}$ $\mathrm{U}=56.6 \%$

Carnotite (カルノー石) $\mathrm{K}_{2}\left(\mathrm{UO}_{2}\right)_{2}\left(\mathrm{VO}_{4}\right)_{2} 3 \mathrm{H}_{2} \mathrm{O}$ $\mathrm{U}=52.8-55.0 \%$

Gummite（ゴム石）閃ウラン鉣の分解生成物

Euxenite (ニークセテイト) ( $\mathrm{Y}, \mathrm{Ca}, \mathrm{Ce}, \mathrm{U}, \mathrm{Th})(\mathrm{Nb}$, $\mathrm{Ta}, \mathrm{Ti})_{2} \mathrm{O}_{6} \mathrm{U}=3-9 \%$

Fergusonite (フェルグンン石) ( $\mathrm{Y}, \mathrm{Er}, \mathrm{Ce}, \mathrm{Fe},(\mathrm{Nb}$, $\mathrm{Ta}, \mathrm{Ti}) \mathrm{O}_{4} \quad \mathrm{U}=0.8-6.3 \%$

Pyrochlore (パイロクロア) $(\mathrm{Na}, \mathrm{Ca})(\mathrm{Nb}, \mathrm{Ta})_{2} \mathrm{O}_{6} \mathrm{~F}$ 通常のむのはU $=1.4 \%$ 以下であるが，U含有率の高い変 種もあ而。

Ellsworthite パイロクロアの変種でU含有率が高い $\mathrm{U}=17.1 \%$

Hatchettolite 同上 $U=14 \%$

Samarskite (サマルスキー石) (Y, Ce, U, Ca, Fe, $\mathrm{Pb}, \mathrm{Th})(\mathrm{Nb}, \mathrm{Ta}, \mathrm{Ti}, \mathrm{Sn})_{2} \mathrm{O}_{6} \mathrm{U}=8.4-16.1 \%$ (瀬戸)

\section{7) Drewboys 重液選炭機}

The Drewboys Washer. Ore-Dressing Notes (8) Coal (Mining Magazine, March 1954, 155-156)

これは英国石㞸庁 (National Coal Board) 発行の Information Circular No. 53/90 に紹介された新しい 重液選炭機で，現在フランスだけで約 20 台操業されて抗

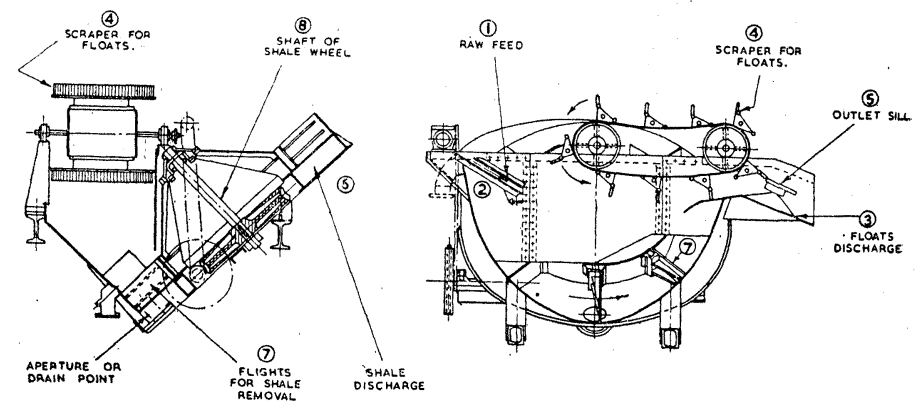

策 1 図

り，英国でも数台製作中ということである。その構造は 第1図に示す如く，本体は急傾斜の側面を有するタンク 加成り，一側面に沈炭 (廃石) 排出用の回転式フラィ 
ト・コンベャをもつている。浮炭（精炭）はスクレーパ 一(4)によつてタンクの一端(から排出される。重液（重 液材としては通常磁鉄鉱が使用される) は(2)から分離槽 (タンク)度横切つて静かに流れ，浮炭の運動を助ける。 沈炭をかき集めてタンクの一端(6から排出するための回 転式フライト・コン心゙ャ(7)は, 傾斜 $45^{\circ}$ の軸(8)の周りに 回転するようになつており，その軸受は軍液と接觸しな いように充分保護されている。この重液選炭機の特長は 給炭中の廃石量の大幅の変動に対して順応し得る点にあ ると云わ机ている。

次に或る選炭工場の例を挙げると Drewboys 重液選 炭機の給炭の粒度は 300 50mm, タンクの寸法は重液 面で幅 $2.00 \mathrm{~m}$, 長さ $2.05 \mathrm{~m}$, 回転式フライト・コンぶヤ の直径は $3.70 \mathrm{~m}$, 重液の比重は 1.95 である。ここでは 従来の手選の代りに本機を採用したのであつて，その浮 炭はさらにジグで処理される。浮炭およで沈炭はそれぞ れ別々に脱液・洗滌される点は一般の重液選炭々同様で ある。重液材 (磁鉄鉣) の粒度分析は次の通りである。

$$
\begin{aligned}
& +147 \mu \ldots \ldots \ldots \ldots . . . .2 \% \\
& -147+44 \mu \cdots \cdots \ldots \ldots . . . .48 \% \\
& -44+20 \mu \cdots \cdots \cdots \cdots . . . .45 \% \\
& -20 \mu \quad \cdots \cdots \cdots . . . . .5 \% \\
& \text { 許 } 100 \%
\end{aligned}
$$

給炭量は平均 $136.5 \mathrm{t} / \mathrm{h}, そ$ ，のうち浮炭は $98 \mathrm{t} / \mathrm{h}(72 \%)$ で ある。重液材の消費量は給崖 $1 \mathrm{t}$ 当り約 $380 \mathrm{~g}$ である。

もう一つのフランスの選炭工場では, やはり人件費の 昂騰から本機による重液選炭を採用するに至つたもので 現在手選廃石 1,300t/日 比重 1.92 の重液を用いて処理 し，浮炭すなわちミドリング（25\%）と沈炭すなわち廃 石 $(75 \%)$ とに分離している。ミドリングはさらに別途 再処理される。人員は 1 方 2 名, 重液材損失量は約 $310 \mathrm{~g} / \mathrm{t}$ である。

(今泉)

\section{治金}

\section{8）New Carlton 工場の流体焙燒}

T. B. Counselman : Fluo Solids Roasting at The New Carlton Mill.

(Mining Congress Journal, March 1954. p.53 55)

Golden Cycle 会社では永年 Colorado Spring に工 場を設け Cripple Creeke 地方の諸鉱山からの鉣石を 汽車で運搬し $\mathrm{Te}$ 存除く為に焙焼後青化に附していた。 焙焼は石炭支燃料とする8基の Edwards 焙焼炉で処理 していた。これを廃止して Carlton 工場が Cripple Creek 及び Victor の間に建設され単一浮選精鉣を暗 焼する事にした。精鉱は約 $22 \% \mathrm{~S}$ 去含有するのでそれを 熱源に利用するにある。この為石宸を運搬する事も不要 になつた。
Dorr 会社の手で Conn, 州 Westport で綰密な試験 が行われた。80\%固体の Slurry でSが 20\% 又はえれ 以上あれば操業可能で焙焼後の青化の成績も優秀であつ た。そこで Carlton工場に炉が建設されるに至つた。炉 は1951年 4 月に操業開始され途中1951年 9 月加ら1952年 1 月汽コットレル建設の為中止し後1953年 3 月汽調查の 為操業を休止する汽は休まず継続した。

炉は断熱煉瓦及び耐火煉瓦で内張りしたもので内径14 呎である。精鉱妈理能力S $20 \%$ で 1 日当り $65 \mathrm{t}$, 最高75 $\mathrm{t}$ 最低50 t である。一の方又は一，二の方操業して残り は吹止する。吹止は簡単で単に空気と鈗石の装大を止め る文である。1100〜 $1200^{\circ} \mathrm{F}$ の炉は漸次熱を失い一の方 又は二の方で吹止した後吹立てるには送風及び鉱石を装 大する丈で簡単である。36時間吹止して後吹立てたが熱 を加えなくとも容易に出来た例もある。この流体焙焼の

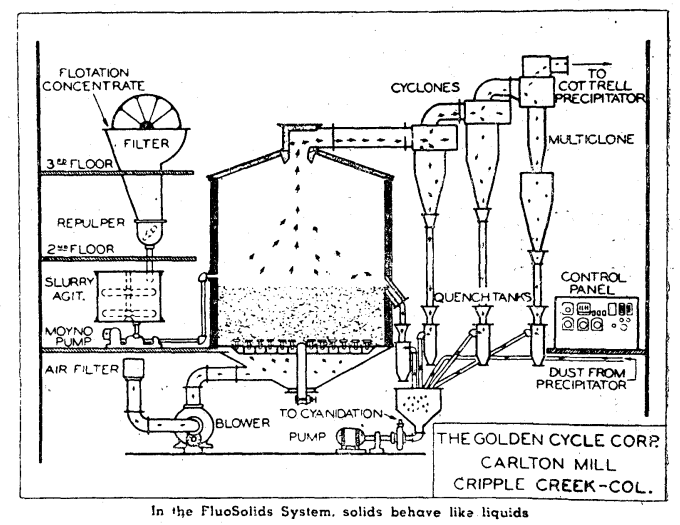

特性は週末吹止出来る事, 又操業中修縉の為吹止出来る 事等はかり知れぬ特点がある。当所の炉は装大割合 1 日 当り $5 \mathrm{t}$, 空気量 $1100 \mathrm{~m}^{3}$, 約 $2 \mathrm{x} / 2 \mathrm{p} . \mathrm{s}$. 压。鉌層厚 4 呎

\begin{tabular}{|c|c|}
\hline 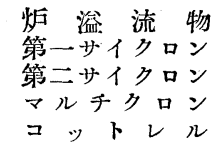 & $\begin{array}{r}\text { 燒鉱の } 60 \% \\
\text { " } 30 \% \\
\text { " } 4 \% \\
\text { " } 2 \% \\
\text { " } \quad 4 \%\end{array}$ \\
\hline 計 & $" 100 \%$ \\
\hline
\end{tabular}
6 时である。

Slurry 装入は図示する通りフイルターで濾過され必 要な水分にリパルプされる。これは肉眼判定による。こ れを 1 分間90迴転の Moyno Pump で炉に送る。焼鉣 の粗いのは溢流し細い のは二段のサイクロ ン, マルチクロン， = ットレルで捕集する。 その分布例を示せば左 表の通りである。

排がスの分析は $\mathrm{SO}_{2} 14 \%, \mathrm{SO}_{3}$ 及 $\mathrm{CO}_{2} 2 \%, \mathrm{O}_{2} 1 \%$ 以下 である。焼鉱は全部水で浸出普通の Merril-Crowe, C. C. D. 青化法に附する。

架気量を加減して焙焼法を調べた。焼鉱の色で黒色, チョコレート色, 赤色と名つけている。只の結果を次に 示す。 


\begin{tabular}{|c|c|c|c|}
\hline & 黑 色 & $\mid \begin{array}{l}\text { チョコレ } \\
-\quad \text { 色 }\end{array}$ & 赤 色 \\
\hline $\mathrm{Au}$ 回收率 $(\%)$ & 88.10 & 91.44 & 94.70 \\
\hline $\mathrm{CaO}$ 消費量(1b/ton) & 7.22 & 6.82 & 8.61 \\
\hline $\mathrm{NaCN}$ 消䙼量(1b/ton) & 4.58 & 3.44 & 2.58 \\
\hline 使用過剩密気量 $(\%)$ & 2.0 & 4.5 & 11.6 \\
\hline 流動用埊践 $(\mathrm{cfm})$ & 1100 & 1100 & 1100 \\
\hline 裝入 (固体割合\%) & 79.1 & 79.5 & 80.0 \\
\hline 㴓度規正噴霧水量 $(\mathrm{gpm})$ & 1.5 & 1. & 1.9 \\
\hline 排ガス $\quad \mathrm{SO}_{3}(\%)$ & & 14.9 & 12.2 \\
\hline $\begin{array}{r}\mathrm{SO}_{3}+\mathrm{CO}_{2}(\%) \\
\mathrm{O}(\%)\end{array}$ & & $\begin{array}{l}1.9 \\
0.8\end{array}$ & 2.1 \\
\hline $\mathrm{Au} \quad(\mathrm{Oz})$ & 7.76 & 8.55 & $\begin{array}{l}2.1 \\
9.09\end{array}$ \\
\hline $\mathrm{S}(\%)$ & 22.4 & & 24.3 \\
\hline $\mathrm{Fe}$ & 21.4 & 22 & 23.1 \\
\hline Ins. $(\%)$ & 45.6 & 44.7 & 41.3 \\
\hline $\mathrm{Au} \quad(\mathrm{Oz})$ & 9.53 & & 10.59 \\
\hline Sulphide $\mathrm{S}(\%)$ & 0.51 & 0.55 & 0.17 \\
\hline
\end{tabular}

チョコレート色焼鉱が金の実収率及び試薬消費量から 見て最良の條件にあるこをを示したので通常肉腿判定で チョコレート色に焙焼操業する事にした。焼鉱の黑色は 磁鉄鉱, 赤色は赤鉄鉱, チョコレート色は両者の混合物 を含有する為であるとされている。

当工場好理粗釷約 150,000 $\mathrm{t}$ 濃䌐比 $20 ： 1$ (平均焼鉣 約 $7,500 \mathrm{t}$ ) で一年間操業の焙焼費は焼鈸 $\mathrm{t}$ 当り $\$ 3.40$ と

\begin{tabular}{|c|c|}
\hline 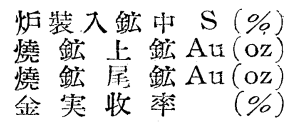 & $\begin{array}{r}22.91 \\
4.45 \\
0.14 \\
96.85\end{array}$ \\
\hline
\end{tabular}

\begin{tabular}{r|r|r}
\hline メッシュ & ミタロン & Cum.\% \\
\hline 35 & 417 & 0.1 \\
48 & 295 & 0.5 \\
65 & 208 & 3.1 \\
100 & 147 & 11.7 \\
150 & 104 & 24.6 \\
200 & 74 & 36.0 \\
& 60 & 44.0 \\
& 40 & 58.0 \\
& 30 & 66.0 \\
& 20 & 76.0 \\
& 10 & 87.2 \\
& 8 & 89.7 \\
& 5 & 93.8 \\
\hline
\end{tabular}
いう。流体焙焼設 置の目的は先述し た外に尾鉱のAu を全体で $0.020 z$ 攵 はえれ以下にする にあつた。青化法 迄一貫して尾鉣は Au0.010oz以下に なりその目的も十 分に果せた。今平 均一カ月の数字を 示すと左上表の通 りである。

操業中問題とし たのは非常に微細
な焼鉣の捕集であつた。今一例として赤色焼鉱の時の炉 装大物の節別試験を示せば前掲下表の通りである。 又各種サイクロンの収塵率は次の通りであつた。

第一サイクロン (Western Precipitation Type)

$$
\text { 第一，第二サイクロン（同上） } 86 \%
$$$$
\text { 第一,第二サイクロン,マルチクロン（同上） } 90.3 \%
$$

又焼鉱の金の分析は次の様であつた。

$\begin{array}{lrl}\text { 裝入鈗 } & \text { Au } 9.09 \mathrm{oz} / \mathrm{t} \\ \text { 炬溢流物 } & \text { " } 5.26 " \\ \text { 第一サイクロン } & \text { " } 16.46 \text { " } \\ \text { 筇二サイクロン } & \text { " } 19.22 \text { " } \\ \text { マルチクロン } & \text { " } 17.35 \text { " }\end{array}$

収鹿率の向上，実収率の向上の為にコットレル建設の 要望が出て会社所有の旧設備在改修してこれに当てた。 その結果全焼鉱の $4.6 \%$,溢流の $9.3 \%$ の回収増加を見た。 煙突は鋼板製ではSOュがスによる腐蝕で寿命が約 2 力 年とされている事を考えカデダの某工場ではタイル張の 建設をしているのに対して当工場では不銹鋼で作れ!゙安 全といい婳中との事である。

(瀬川)

\section{9）Oker における連続法による 鉛精製}

Jürgen Feiser, Helmut Börger Georg Krahm: Bleiraffination nach dem kontinuierlichen Verfahren atif der Bleikupferhütte Oker

(Erzmetall : B.VII Heft 1. S. 1〜3 1954)

粗鉛精製のための連続式反射炉を作るに当り， Williams, F. A. Green による Port Pirie の操業報 告々 Oker の場合には次の諸点の相違がある。

1) 精製する粗鉛の量は Port Pirie の 1/6〜1/7にす ぎない。

2) 含まれる不純物，Sb，As，Snの量は広い範囲に

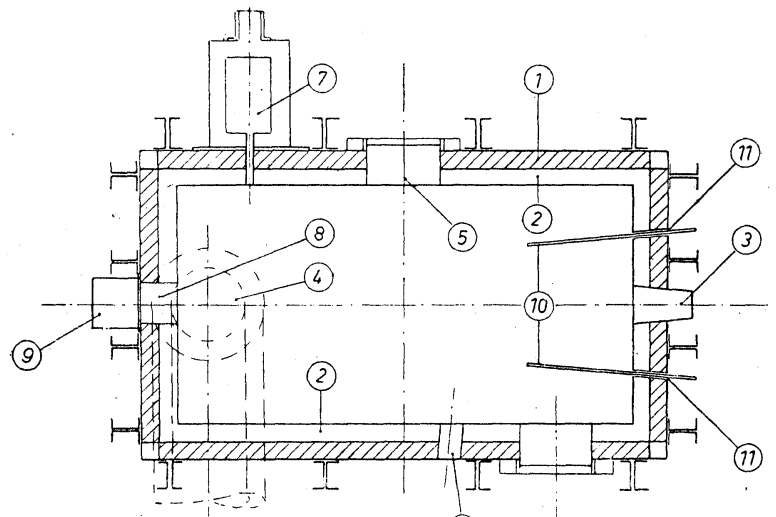

(5)

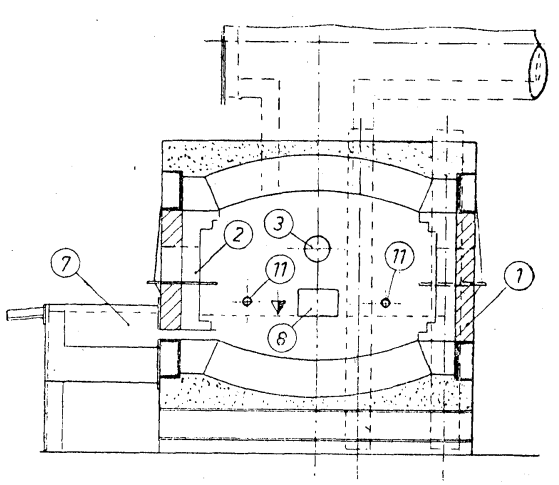


わたり変化している。

3) 炬材ステアタイトはドイッでは高価である。これ らのことを注意して以下述べる炉を作つたのである。

裝置—炉は連続操業に必要な僅かの附属設備の付い た普通の反射炉である。内法りは長さ $3.0 \mathrm{~m}$ ，幅 $1.5 \mathrm{~m}$ ， 湯の表面積は $4.5 \mathrm{~m}^{2}$ である。図の (1) 炬耐火物冷却用 水套，(2)マグネシャ煉瓦，炉底及び天井の厚さ $250 \mathrm{mm，}$ 炉壁厚を $120 \mathrm{~mm}$ ，接続個所を少なくするために出来る だけ大きな徚瓦を用いる。(3)加熱用バーテー，湯面と $30^{\circ}$ の角をなし $1,350 \mathrm{kcal} / \mathrm{Nm}^{3}$ の発生炉がスを最大 $500 \mathrm{Nm}^{3} / \mathrm{h}$ 吹き込み得る。燃燒用空気は $1,000 \mathrm{Nm}^{3} / \mathrm{h}$ 容 量のベンチレーターを用い, 炉の廃ガスで $300 \sim 400^{\circ} \mathrm{C}$ に予熱する。(4)燃焼廃がス出口，バーテーの反対側にあ りレキュペレーターに行く。(5)修理文はのぞき用空，(6) 鉊装大口, 脱銅処理後の鉛を鍋に入れ $450^{\circ} \mathrm{C}$ で装入す る。炬内の鉊は $15 \mathrm{t}$ で炉内平均滞留時間は 1 2 時間で ある。7鉛取出し口, 装入口之対角線の位置にあり, 取 出した鉛を脱銀工程に移す。8浮㵏取出し口，(9)浮㵏流 出口, 両方ともマグネシヤ燌瓦でライニングする。浮滓 取出し口の高さは鉛の流出用の樋の高さと同じにする。 (図中点線)浮㳯の層の厚さが 50〜100mm になつた時に 鉊の流れ出るのを止め浮滓を流し出す。110圧縮空気吹込 み用鉄管，必要な最小風圧は 3 気圧である。Port Pirie の場合には $1 \sim 1 \pi / 2^{\prime \prime} \phi$ の水冷鉄管を用いているが，ここ では鉛量が少なく水冷すると鉄管の迴りに鉊が㠜固して 来るので水冷せず $3 / 8$ " $\phi$, 長さ $3 \mathrm{~m}$ の鉄管を用いる。(11) 鉄管装大用の穴, $56 \mathrm{~mm} \phi$ 。

操業方法一一装入する粗銛は 60〜65 $\mathrm{t}$ の鍋より.移さ れる。As, Si， Snの含有量により必要な処理時間は異 なるが大体 4〜8 時間, すなわち 1 時間に 8〜16t の鉛
が連続的に精製される。精鍊の初期に加熱及び不純物 のはげしい酸化により湯の温度は $800^{\circ} \mathrm{C} に$ 昇るが間も なく $760 〜 780^{\circ} \mathrm{C}$ となる。精製期間の操 業温度維持に 必要な熱量は酸化反応による発熱によつて与えられるが Port Pirie の場合之異なり処理量が少ないため, バー ナーで $50 \sim 100 \mathrm{Nm}^{3} / \mathrm{h}$ のガスを然焼 加熱する。このこ とは鉛の表面にある浮滓を同時に加熱し浮滓を愹融状態 にして除去し易くするばかりでなく炬中で平衡状態に早 く到達すると云う利点をも有する。取り出す鉛の温度を $760 \sim 780^{\circ} \mathrm{C}$ に保ち湯の攪挥を充分にすれば単位時間の 処理量は不純物の含有量によつて決まる。

操業結果—-1952年 2 月操業開始より 1953 年 11 月末 までに約 18,000t を精製した。この炉の湯の表面積は 僅か $4.5 \mathrm{~m}^{2}$ にすぎないが，今までは $34 \mathrm{~m}^{2}$ の 2 基の反 射炉を必要とした。精製前の粗鉱の品位は $1.0 〜 3.0 \%$ $\mathrm{Sb}, \quad 0.05 \sim 0.5 \% \mathrm{As}, 0.1 \sim 0.25 \% \mathrm{Sn}$ であり, 精製後 の鉊は $0.05 \sim 0.1 \% \mathrm{Sb}$ である。As，Sn は両者合せて $0.01 \%$ 以下となる。浮㵏は 12〜15\% Sij，0.5〜2.0\% As, $0.2 \sim 0.4 \% \mathrm{Sn}, 0.01 \% \mathrm{Cu}, 8 \sim 12 \mathrm{~g} / \mathrm{t} \mathrm{Ag}, 5 \sim 10$ $\mathrm{g} / \mathrm{t} \mathrm{Bi}$ となる。 Ag の含有量の低い粗 鉛の精 製の場合 には浮滓と鉛の分離は非常に良く浮滓は脱銀せずそのま ま硬鉛の原料となる。又浮㵏と鉛の分離が良いため浮㳯 中の Bi は非常に少ない。不純物の酸化除去される速度 はその含有量によるが 1 時間, $1 \mathrm{~m}^{2}$ 当り $35 \sim 50 \mathrm{~kg}$ の $\mathrm{Sb}, \mathrm{As}, \mathrm{Sn}$ が酸化され，非連続法の場合に比較すると 約 10 倍の速さである。燃料の消費は今までの方法の約 $1 / 3$ となり耐火材は処理粗鉛 $\mathrm{t}$ 当り 2〜3kg 必要である。 内張りの寿命は約 4 カ月で王力空気吹き込久用鉄管は処 理粗鉛 $20 \mathrm{t}$ 当り $1 \mathrm{~m}$ の割で消耗する。文人件費も今ま での方法に比して大いに低隇される。

(後藤)
（14頁より続く）

\section{$\checkmark$ ERZMETALL}

\section{Ba. VII H. 2}

- Hermann Findel: Der Gesteinsstrecken vortrieo im Metallerzbergbau, unter bésonderer Berücksichtigung der Harzer Verhältnisse. - Walter Müller : Neuzeitliche Gesichtspunkte für das Auffahren von Gesteinsstrecken - Otto Arnold: Über Verschleissfragen in der Aufbereitung Ramsbeck. - Gotthard Björling : Ein Beitrag zur Ther- modynamik der Kondeasation von $Z$ ink.

\section{SCHLÄGEL und EISEN}

Feb. 1954

-Walter striebeck : Apparatur für die Verspritzung stark viskoser Flüssigkeiten unter Tage - C. Hoffmann: Das HauhincoBetriebsprüfgerät für Abbauhämmer und seine Anwendung

- Otto Christoph : Neuartige Druckluft-Schlauchleitung in dünnen Flözen.

\section{Warld Mining}

Vol. 7 No. 3

- Are Your Drilling Costs Too High? - New West Hill Plant Points Way To Mining of Leaner Mesabi Iron Ores. - Iron Ore From Cerro Bolivar.

$$
\text { その 他 }
$$

\section{○資源 29年 3 月}

- 主要鉱物の埋蔵量と鉱業の遛勢 (小帠鎭雄)

\section{○製鉄研究 54.3}

-八幡製鉄所に打ける石炭水選作業 の変遷（柴田与七郎） 